\title{
Assessing the Recreation Value of Urban Woodland Using the Ecosystem Service Approach in Two Forests in the Munich Metropolitan Region
}

\author{
Gerd Lupp ${ }^{1, *}$, Bernhard Förster ${ }^{1}$, Valerie Kantelberg ${ }^{2}$, Tim Markmann ${ }^{1}$, Johannes Naumann ${ }^{1}$, \\ Carolina Honert ${ }^{2}$, Marc Koch ${ }^{2}$ and Stephan Pauleit ${ }^{1}$ \\ 1 Chair for Strategic Landscape Planning and Management, Technical University of Munich, 85354 Freising, \\ Germany; bernhard.foerster@lrz.tu-muenchen.de (B.F.); tim.markmann@web.de (T.M.); \\ johannes-naumann@gmx.de (J.N.); pauleit@wzw.tum.de (S.P.) \\ 2 Department 7 "Forest ownership, Counseling, Forest policy", Bavarian State Institute of Forestry, \\ 85354 Freising, Germany; valerie.kantelberg@lwf.bayern.de (V.K.); carolina.honert@lwf.bayern.de (C.H.); \\ marc.koch@lwf.bayern.de (M.K.) \\ * Correspondence: gerd.lupp@tum.de or luppg@gmx.de; Tel.: +49-8161-71-4661
}

Academic Editors: Karsten Grunewald and Olaf Bastian

Received: 23 August 2016; Accepted: 2 November 2016; Published: 10 November 2016

\begin{abstract}
Recreation is considered an important ecosystem services (ES) in urban woodlands and puts pressure on other ES. Visitor management strategies can be tools to safeguard biodiversity and ES. On-site data are necessary to evaluate the demand for outdoor recreation opportunities in urban woodlands, but also for providing more reliable values for monetization as a basis for multifunctional forest management, and for raising awareness for the importance of urban proximate forests. Such information can also be used for the assessment and monetization of socio-cultural ES, and hence, contribute to developing market-based mechanisms or to promoting these ES. In our paper, we demonstrate methods to describe recreational demand by collecting data from interviews and using camera traps in two forests in the north of Munich for visitor counting. Visitor numbers in the forests were much greater than rough estimations; visitors also had quite long travelling distances to the forests. Jogging or Nordic walking were proven to be important recreational activities. In some of the monitored locations, almost half of the recreationists carried out these sports. Depending on the method chosen, the calculative monetary value of recreation reached up to 15,440 Euro per hectare per year.
\end{abstract}

Keywords: woodlands; ecosystem services (ES); mapping recreational use; user groups; visitor numbers; interviews; camera traps; values of ES

\section{Introduction}

The concept of ecosystem services (ES) as a theoretical framework stresses the essential relevance of ecosystem structures and processes to mental and physical well-being. It encompasses both the supply and demand of services. It can play a role as an eye-opening metaphor and a tool for society to better conserve and enhance the natural capital in decision making [1]. The links between ecosystems, their goods and services, and their contribution to human well-being have been globally assessed in the Millennium Ecosystem Assessment [2]. The degradation of ecosystems and their ability to provide goods and services would also lead to negative consequences and economic costs for society [3]. Especially the "Economics of Ecosystems and Biodiversity" (TEEB) studies [4] had a considerable influence on policy debates and policy making such as the integration of economics of ecosystems and biodiversity in the strategic plan concerning with regard to the EU biodiversity strategy and that of respective EU member states, such as that implemented in Germany until 2020 [5]. 
Urban woodlands (we understand the terms "urban woodland" as forests according to the German Federal Law Section 2 within the boundaries of a city or a metropolitan area) provide many different ecosystem services (ES) for built-up areas and provide benefits for the sustainable development of metropolitan areas [6-9]. Contributing to the nodes and patches of green-infrastructure in cityscapes [10], they provide provisioning services such as drinking water or timber; regulating services like flood protection or air pollution control, supporting services such as maintenance of biodiversity and numerous cultural services, e.g., recreation opportunities. In urban woodlands, recreation opportunities are considered to be one of the most important ES [11]. Recreation activities such as walking or cycling have a positive effect on health [12]. Greenspace and forests in the vicinity of residential areas stimulate people to visit those places more frequently [7]. In England, access to quality green space potentially saves the National Health Service (NHS) around $£ 2.1$ billion in health care costs, and even savings of up to $£ 1.44$ billion (in health care costs) could be achieved with a $1 \%$ reduction in sedentary behavior [13].

Moreover, outdoor recreation has changed, and a number of new recreational activities have evolved in recent years such as mountain biking, Nordic walking, or geo-caching [14]. The demand for recreation opportunities, hand in hand with increasing visitor numbers in urban woodlands, is expected to increase due to population growth in urban areas. Moreover, as a consequence of climate change, such urban woodlands can serve as "cool islands" [8,15].

Recreational activities can put anthropogenically derived pressure on urban woodland ecosystems and their ability to provide ES [16,17]: Recreation can cause soil erosion, vegetation loss, and pollution, and thereby the potential to provide related ES is reduced. Visitor management and steering of visitor flows can be tools to safeguard biodiversity and ES [18]. Also, a number of forest management measures can enhance both the provision of opportunities for outdoor recreation in forests and aesthetic quality by providing marked fitness trails or by preserving eye-catching old, tall, and bizarrely-shaped trees along the trails [19-24].

To assess and evaluate the demand for outdoor recreation opportunities, there is a need to estimate total visitor numbers in urban woodlands, the distribution of visitors as well as the length of stays in a forest [25]. Such data are vital to understand the demand for socio-cultural ES and ultimately, for providing more reliable values and monetization as a basis for management and for raising awareness of the importance of urban proximate forests and their potential benefits for urban areas.

In Germany, the public has the right to freely access forests, even if they are privately owned. Recreation, therefore, is widely a non-market service, and real demand for outdoor recreation has often not been assessed in detail. An overview of the state-of-the-art approaches for systematic visitor counting can be found for Central Europe in [26] and in the various MMV (monitoring and management of visitor flows in protected areas) conference proceedings [27-31]. According to these papers, systematic data collection is mainly conducted in large protected areas such as National Parks. Information is frequently based on verbal reports of visitors, guesses by area managers or, typically, by rough estimates [32]. A prime example is the planning guidelines for recreational forests within the Federal Free State of Bavaria [33]. A grade 1 recreational forest with respective management practices is defined as a forest with more than 10 visitors per day and per hectare on a peak day. This classification being a grade 1 recreational forest is based on experience or estimates, such as the number of cars parked related to the respective area. These methods are suitable to roughly estimate visitor numbers; however, they tend to be imprecise and are often subjectively biased [25].

Land-owners and forest managers face costs for providing recreational opportunities in urban woodlands. Data from Germany indicate a calculative loss of income of around 18 Euro per hectare per year, mainly due to increased efforts to cope with liability issues for forest visitors, with restrictions in timber harvesting and to deal with the selection of less vigorous tree species [34]. Seintsch et al. [35] calculated an average cost for recreation of 58 Euro per hectare per year for state-owned forests, 21 Euro per year per hectare for community forests and 3 Euro per hectare per year for privately owned forests. Therefore, a sound census on visitor numbers and their demands might help to better understand the 
value of socio-cultural ES and better support the multifunctional management of urban woodlands [11]. Census data also provide a basis for the assessment and monetization of socio-cultural ES, and hence, contribute to developing market-based mechanisms or promotion of these ecosystem services [36].

The assessment of the demand for non-market goods like recreation is carried out by such methods as stated preference techniques, choice experiments, willingness to pay (WTP) to maintain biodiversity, target species, ES, landscape elements, and aesthetic values [37,38]. Also, software tools such as iTree ECO can be applied for assessing many ES [39]. Such assessments are considered useful to highlight the positive effects of nature conservation economically, also in monetary terms [40,41].

Recreation values using visitor numbers have been assessed for protected areas, e.g., a valuation of some ecosystem services and recreation provided by wetlands in the Netherlands by Hein et al. [42]. For forests, assumptions for the recreational use are often very general (see Elsasser et al. [43] with a bibliography, database, and valuation studies in Central Europe, and von Grünigen et al. [44] for Switzerland). While provisioning services are often assessed on the forest level, most of the studies calculating recreational use are based on nationwide household surveys or depend on very basic assumptions [45].

In our paper, we therefore assess the actual on-site recreational use of two forests in the north of the Munich Metropolitan region using camera traps for visitor counting. Interviews were used to gain additional data for both the recreation quality and the importance of various ES for forest visitors, but also to better understand the catchment areas of the two forests and to calculate a monetary value, furthermore, taking into consideration travelling distances. We point out the value of such detailed information and use the data to calculate a recreational value by employing the travel cost method and a "day ticket" approach. By using on-site data, we avoid some of the critical points mentioned by Riera et al. [37] for the travel cost method, in general. We are aware that, by calculating in this way, non-forest visitors are not taken into account.

\section{Materials and Methods}

Two urban woodlands in Freising, around $30 \mathrm{~km}$ away from the city center of Munich serve as our study area. Situated at the southern rim of the lower Bavarian uplands edging towards the Munich plains, they are one of the few larger forested areas in the densely populated area north of Munich. They were selected as part of a study to assess and better understand recreational uses in the Munich metropolitan region [18]. Both forests are also exemplary showcases for the forest authorities aiming to provide especially attractive recreational offers for metropolitan areas.

The area of the "Forest Adventure Trail" ("Walderlebnispfad Freising") directly borders on the city of Freising in the west. Being part of the larger "Wippenhauser Forst", it is state-owned. The recreation area is about 100 ha. It hosts both a fitness trail and the "Forest Adventure Trail", a loop trail, each with a length of approx. $2 \mathrm{~km}$. The adventure trail starts and ends at a beer garden. At 23 stations, information about the forest and biodiversity is given in different forms, playful, inviting exploration or for contemplation. The trail was a project initiated by the local Agenda 21 initiative in cooperation with the Bavarian State Forest Enterprise, the town of Freising, and the "Friends of the World Forest \& Adventure Trail Freising" (www.walderlebnispfad-freising.de). In 2016, around 30\% of the trees were beeches (Fagus sylvatica), 10\% oaks (Quercus robur and Quercus petraea), and 5\% are other broadleaves, $45 \%$ Norway spruce (Picea abies), and $10 \%$ of other conifer species, according to the forest inventory data. According to the methods given in the forest planning guidelines [33], forest staff estimated visitor numbers to be around 35,000 people a year. By observations, e.g., counting cars at the parking lot and by requests for guided tours, the "Forest Adventure Trail" seemed to attract many people from more distant places, also from beyond the northern Munich Metropolitan Region, according to the staff (Herbert Rudolf and Thomas Stör via personal communication).

The "World Forest" (Weltwald Freising) is a state-owned forest of 100 ha in size, located around $4 \mathrm{~km}$ west of Freising in a larger forest called the "Kranzberger Forst". In 1987, it was decided to host an arboretum for both the public and the life science faculties for the two universities 
based in Freising, the Technical University of Munich and the University of Applied Sciences Weihenstephan-Triesdorf. By 2016, more than 300 different tree species had been planted in the forest matrix. Several thematic trails with a total length of $7 \mathrm{~km}$ provide access for exploring typical tree species of different geographical regions in the world. In the center of the forest, an information pavilion and a catholic chapel can be found. Also, sculptures and land art can be experienced in this forest (www.weltwald.de). By 2016, the rough share of tree species was $10 \%$ beech (Fagus sylvatica), $10 \%$ oak (Quercus robur and Quercus petraea), 25\% other broadleaves, $45 \%$ Norway spruce (Picea abies), and $20 \%$ other conifer species according to the forest inventory data. Staff members estimated the visitor numbers to be around 10,000 people per year (Herbert Rudolf and Thomas Stör via personal communication).

For a better understanding of the recreational uses in the two forests and to collect more qualitative data, the camera countings were combined with two interview series that were conducted using the next-to-pass approach [46,47]. One was carried out in late summer and fall 2014 [48] and a second one in December 2015. In the first interview series conducted by Markmann [48], besides demographic data, passers-by were asked to rate the forests and their suitability for recreation mainly using open-ended questions and the free listing technique to sort and classify the respective answers [49]. During this period, 189 people were addressed at the forest trail, and 141 filled in the questionnaire. In the "World Forest", 47 out of 55 passers-by responded to the questions.

In the second interview series, passers-by were asked to draw the trails used or intended to be used during their visit on a map according to Arnberger \& Hinterberger [50], so that their spatial recreation patterns could be determined. Also, passers-by were asked to name the importance of several ecosystem services provided by the two forests. The set of selected ecosystem services was similar to that which Lupp et al. [51] had selected for agricultural landscapes, however, they had been adapted to forest ecosystems. 102 people completed the questionnaire in this second series. We are aware that the sample size of the interviews is small and that more interviews carried out at different times of the year would improve the quality of these additional data.

There are a variety of systems for systematic counting of visitor numbers. The technical requirements like resistance to weather, low power consumption, etc., are high [52,53]. To collect long-term data about visitor numbers and recreation types over one year, we opted to use camera traps. The advantage of this method compared to interviews and manual on-site counting is to provide data $24 \mathrm{~h}$ a day. Moreover, field work is limited to collecting the data and maintenance of the cameras. Visitor monitoring and counting by cameras has been applied sporadically, e.g., by von Jankowski \& Becker [54]. In recent years, thanks to the rapid technological development of digital camera technology, the handling and processing of huge amounts of data have been simplified significantly. In order to fulfill privacy regulations in Germany, camera lenses have to be partially blinded.

To count in frequented areas and catch fast moving people such as bikers, a fast trigger speed and a wide range of the club-shaped zone that activates the camera is essential for gaining good results. Three spots at the "Forest Adventure Trail" and five places at the main access routes to the "World Forest" were selected. One Dörr Snapshot 5.1 with GSM-Module and seven Cuddeback C3 Black Flash cameras were used for this task. The Dörr camera collected data between 15 December 2014 and 25 April 2016 from one place at the "Forest Adventure Trail", while the other cameras were mounted between 1 April 2015 and 12 April 2016.

Since these forests are a prime destination for recreation activities, enormous amounts of data were collected, making it impossible to count passing people by assessing the pictures alone. Therefore, around 90 days were selected for a deeper assessment of the pictures. 20 selected days in April and early May 2015, random days for the whole period (one day per month) and days with remarkable weather conditions, such days with a maximum temperature of over $30^{\circ} \mathrm{C}$ or with more than $20 \mathrm{~mm}$ of rain in one day. The data set from April and early May was also used for this paper to determine the number of different user groups, bearing in mind that user groups are different during the seasons and considering various weather conditions. Based on a regression analysis of the assessed data and 
number of pictures taken, a significant linear correlation $\left(R^{2}: 0.79\right.$ lowest and 0.96 highest) between the number of pictures and passing people (passers-by) was found. The factors were used to multiply the respective factor with the number of pictures taken at each camera in order to estimate the total number of passers-by.

Using the visitor counting numbers and travelling distances data from the interviews, we opted for the travel cost method (TCM), using 0.30 Euro per kilometer based on the 2016 German travel and subsistence expenses that organizations are usually willing to refund or reimburse. Depending on the selected literature, sometimes also a value for the stay in the forest is added [55]. Other suggestions to derive monetary values range from a "willingness to pay" up to calculating an assumed average wage and a multiplication of the time spent for the entire trip. In the two study forests, the average duration of a visit is around $90 \mathrm{~min}$ at the "Forest Adventure Trail" and close to $120 \mathrm{~min}$ in the "World Forest". Although having collected demographic data and the average time spent in the forest, due to a more conservative approach to calculating a value for recreational services of urban woodland, we solely used travel costs using the typical refund or reimburse number of 0.30 Euros per travelled kilometer.

In a second calculation, we used the willingness to pay (WTP) approach. We assumed an average of 2.66 Euro for an "entrance ticket". This value was based on an average value calculated from a literature review for a study in Remscheid [56]. This amount fits well to an estimated daily price for a membership in a gym in the Munich area or within the WTP range described in a study from the Ore Mountains for a day ticket to visit an area of high nature conservation value [57].

\section{Results}

\subsection{Recreational Use of the Forest}

Figures 1 and 2 demonstrate the spatial distribution of the recreational use in the two forests. At the different camera locations, recreational activities can be analyzed. The most used section of the "Forest Adventure Trail" is close to the city and a beer-garden next to the trail. At the "World Forest", the highest use is close to the first parking lot from the city. Recreation patterns differed, in particular, between the monitored sites at the "World Forest" (Figure 2).

\section{"Forest Adventure Trail"}

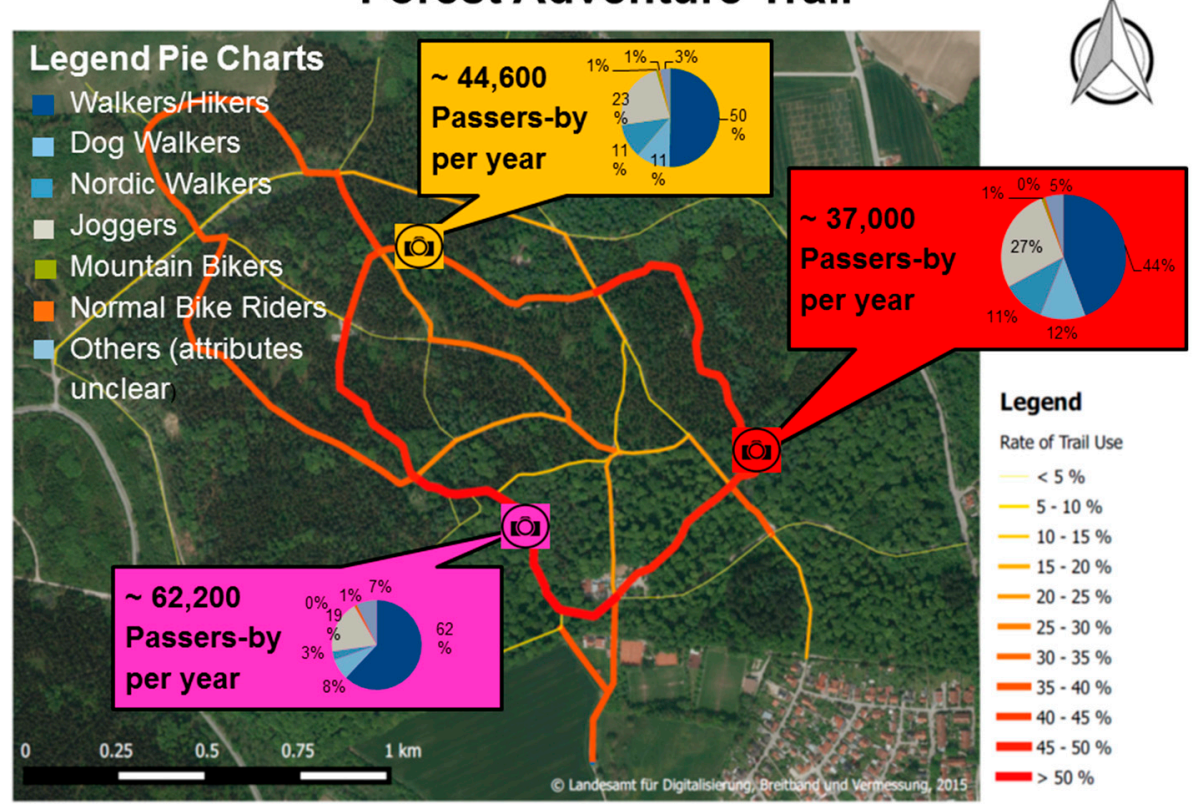

Figure 1. Number of passers-by and trail frequentation at the "Forest Adventure Trail". 


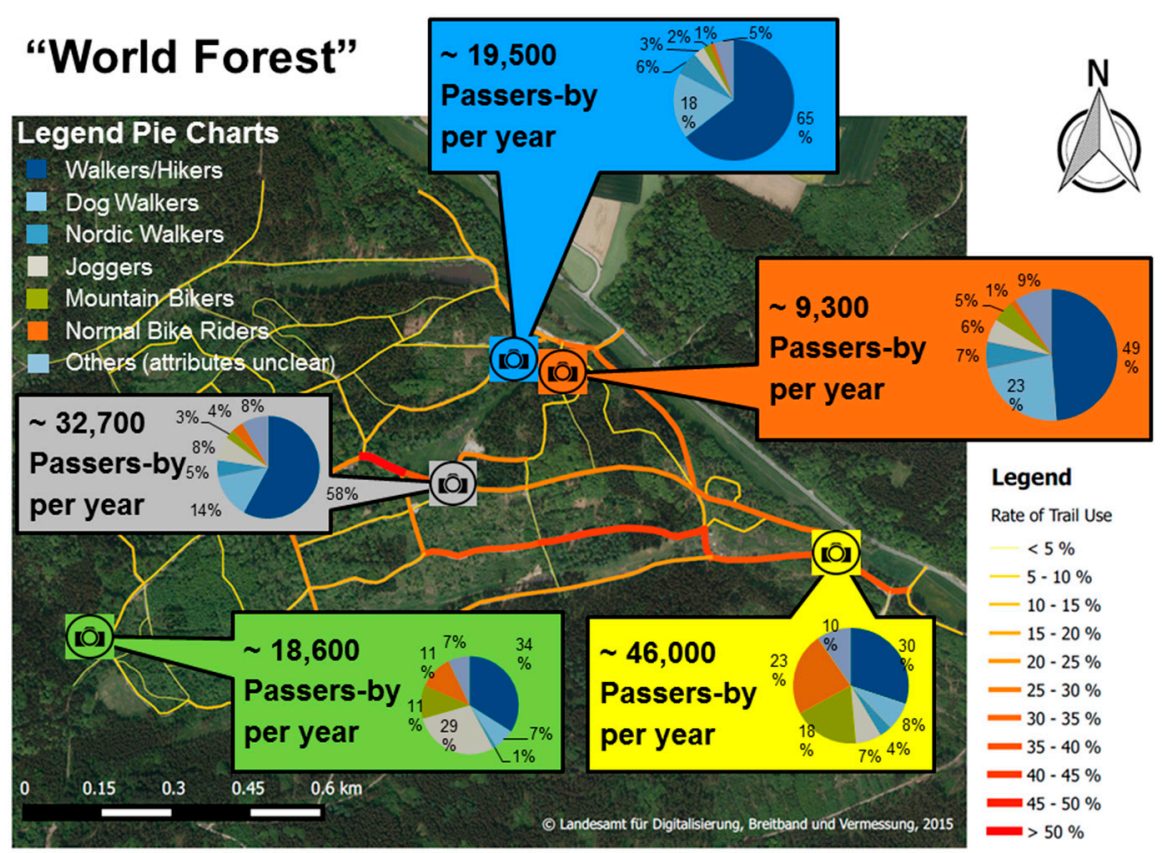

Figure 2. Number of passers-by and trail frequentation at the "World Forest".

\subsubsection{User Groups}

At the "Forest Adventure Trail", almost no cyclists were observed, since riding a bike is not permitted in this forest. Almost one-third of the people at the northern and eastern sections were Joggers or Nordic Walkers.

A more differentiated picture can be drawn in the "World Forest". Especially at the south-eastern entrance, a large number of cyclists were observed. However, for this section we also assume an effect of commuting cyclists between their workplace in the city and their home. The parallel road was highly frequented by fast moving vehicles, and the trails through the forest provided a good alternative car-free route. Some hints such as briefcases in the bike baskets were visible in the blurred pictures. However, in almost every case, it was difficult to distinguish between cycling for recreational purposes and commuting. The trails starting at the north-western parking lot were less frequented. The share of dog walkers was up to $20 \%$ at the monitored sites.

\subsubsection{Demographic Features}

In both forests, females were slightly overrepresented. At the more proximate "Forest Adventure Trail", the age group between 31 and 40 was overrepresented, while in the "World Forest" younger people between 21 and 30 formed the largest age group. In the "World Forest", about half the visitors recreated in pairs, while at the "Forest Adventure Trail" a rough $40 \%$ share of families used this trail for recreation purposes. Comparing the educational level in the interviews, it can be shown that, in general, people with a higher educational level were overrepresented in the forests. The share of people with a higher educational level is higher in the more remote "World Forest". 


\subsection{Monetary Value of Forest Recreation Using the Travel Cost Method and an Assumed "Day Ticket"}

Using the distance between home and the two forests, quite long travelling distances can be observed. One reason might be a lack of forests, especially in the north of the Munich Metropolitan Region, but also marketing of the two places and revisits of school children with their families that have been in these forests for a school outing. The majority of visitors to the "Forest Adventure Trail" travel between $20 \mathrm{~km}$ and $60 \mathrm{~km}$ one way with an average of $57.7 \mathrm{~km}$ one way. Also some long-distance visitors can be observed. For the "World Forest", mainly people from the vicinity driving between $5 \mathrm{~km}$ and $40 \mathrm{~km}$ were observed. The average distance between home and the forest was $29.7 \mathrm{~km}$.

For the "Forest Adventure Trail", we observed around two-thirds of the passers-by moving clockwise according to the suggestions of the sign-posting and the information leaflets, and around one-third going in the anti-clockwise direction. We assumed that the numbers of passers-by at the counting locations represented visitors to the "Forest Adventure Trail". Using the calculated number of passers-by at the most remote place from the parking lot with 44.600 passers, we calculated 1186 Euro WTP and 15,440 Euro TCM per hectare and year.

For the "World Forest", we selected the number of passers-by close to the information pavilion and the chapel in the center of the forest and divided them by 2 , since around half of the people moved "towards" and "away" from this place. Nonetheless, there might be some inaccuracy since people on a round-trip might have passed by only one time or other used trails were not monitored as people were not interested in visiting this place. We, therefore, calculated with around 16.350 visits to the forest which roughly tallies with the same figures as total numbers at the monitored different entrances. We calculated a recreation value of 434.91 Euro WTP and 2913.57 Euro TCM per hectare and year. Revenue for timber is around 70 Euro per cubic meter, and forests in this region have an annual average increment of 8 cubic meters per hectare, so timber value is around 560 Euro per hectare.

\subsection{Attractiveness of the Forests for Recreation}

When asked about the positive characteristics of the forest in an open-ended question without given answers using the free listing technique, most interviewees associated "Nature" and respective natural features with the forest (36\% at the "Forest Adventure Trail", $45 \%$ at the "World Forest"). Especially at the "World Forest", informing and inspiring visitors are core goals of forest management, but only $5 \%$ of the interviewees named this aspect in an open-ended question. When asked about the most favorite thing, again, most interviewees mentioned the natural features and the diversity of the forest. Interestingly, in the "World Forest" with its dedicated offers, no person referred to these opportunities for informing and learning. Negative features were mainly bad sign-posting/bad recreation infrastructure (41\%) and crowding (12\%) along the "Forest Adventure Trail". At the "World Forest" noise (37.5\% as the forest is situated in one of the flight paths of Munich Airport), signage, and trail infrastructure (19\%), and aesthetic qualities of the forest (19\%) were disliked most. The "World Forest" was rated overall with a 4.25 and the "Forest Adventure Trail" with a 4.05 out of 5.

\subsection{Importance of Ecosystem Services}

Interviewees were asked to rank their personal importance of forest ecosystem services provided by these two forests on a 1 to 5 Likert scale. A set of 17 given ecosystem services was presented with an option to add features. The most important features were: "Air purification", "Habitat for pollinating insects", and "Habitat for plants and animals". Provisioning services such as timber, fuelwood, but also berries and mushrooms were of less importance (Figure 3). 


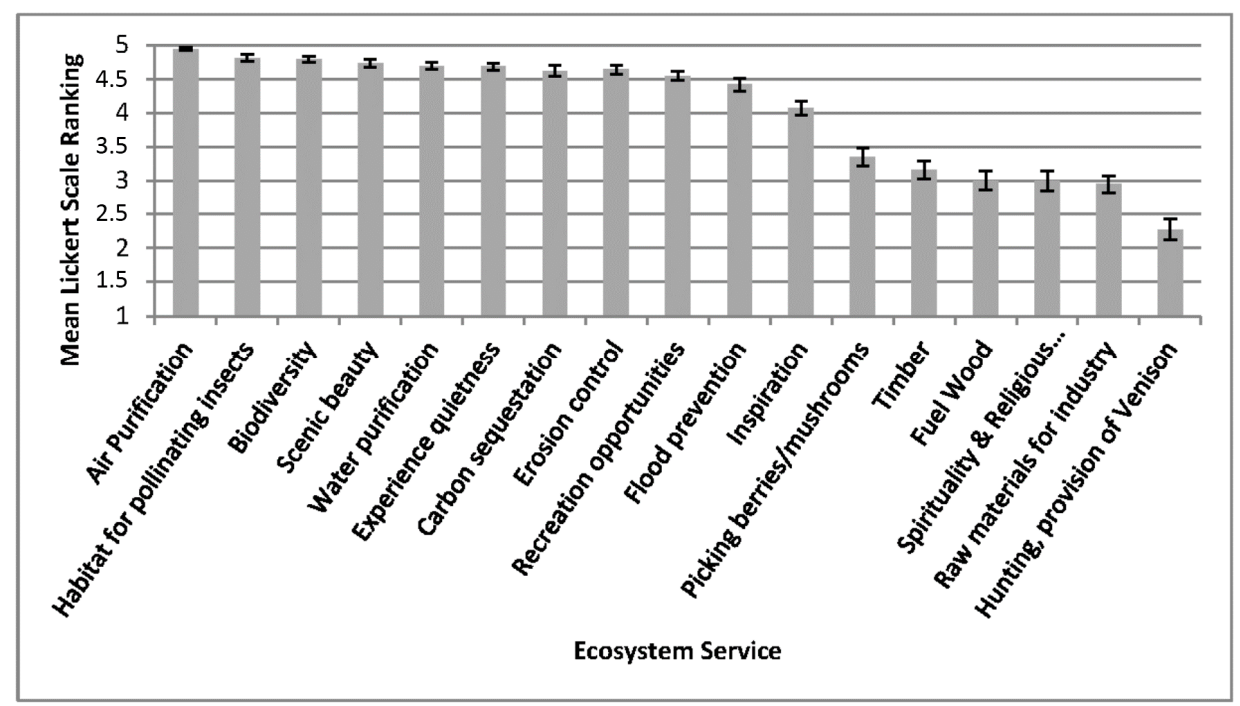

Figure 3. Average ranking of ES by interviewees in the two forests (total $N=102$ ).

\section{Discussion}

\subsection{Data Quality of Camera Traps}

Arnberger \& Haider [58] compared manual counting with that of using camera based systems. The difference between the two methods was below $15 \%$. In highly frequented areas, the camera tends to provide higher accuracy while cyclists tend to be undercounted. In our counting approach, we observed some undercounting especially in difficult terrain and where cameras were mounted on exposed locations [59]. Counting errors seem to be tolerable and estimated within the range or even lower than other technical counting systems. Nonetheless, there is a need for more studies comparing different technical counting systems and further validation of counted results.

The use of camera traps provides a number of advantages compared to other means of visitor counting and provides numerous options for analyses of various issues, especially when combined with other methodological approaches such as interviews. Precise counting supports important management issues. Especially the quantification for sports activities such as jogging or Nordic walking with particular requirements for infrastructure, or potential conflicting uses such as off-leash dogs, is necessary $[18,60]$.

\subsection{Using On-Site Data Collection versus General Calculations}

Compared to many studies dealing with recreational values [43], our study is based on real on-site visitor counts and monitoring as well as on-site interviews. Therefore, the findings encompass real uses of recreational opportunities. We found that the intensity of recreational activities has specific spatial patterns in the two forests: it is highest in the forests close to the city, at the entrances and along main routes, and lower in more remote parts of the forest, although also in these places, infrastructure is provided. Concerning the origin of the visitors, it could be shown that the two examined urban woodlands provide recreation not only for the local inhabitants of Freising, but also provide recreation even for visitors beyond the Munich Metropolitan Region. Therefore, it is quite difficult to relate general statements for forest visits in household surveys to the surrounding forests as assumed in many of the recreation value studies to date [43-45]. Also, modelling of accessibility of greenspace [14] does not fully consider these effects. Our results show the importance of combined on-site counting and interview approaches when studying recreational issues in urban woodlands. 


\subsection{Comparison of Recreational Patterns with Other Studies}

A number of studies provide insights into recreational patterns. Similar to the results from other studies and literature reviews such as Roovers et al. [46], the preferred recreation activity in forests was walking and hiking. The amount of cyclists is variable between the studies and depended more on factors such as relief of the respective study areas and their demographic characteristics (e.g., a large share of students, lifestyles) or policies promoting cycling in everyday traffic [12]. In the "World Forest", we can observe up to $41 \%$ of cyclists as a consequence of these factors. This large share at one of the sites also resulted from the number of commuters. Already Roovers et al. [46] had shown this previously.

Wippermann \& Wippermann [61] mentioned a correlation of educational levels and more frequent visits in forests. An above average share of people with higher degrees can be found in many studies, such as in Finland [62] or in protected areas in Germany [41]. The average time spent in urban woodlands between 90 and 120 min was similar with other studies in Europe [10,62-66]. Only Tyrväinen [66] reports for Finland more frequent, however, these were shorter forest visits of around 30 to $60 \mathrm{~min}$.

In comparison with the study from Belgium by Roovers [46], it can be stated that travel distances only for the World Forest show similarities. The Forest Adventure Trail has much longer distances. However, this trail is marketed as a prime destination in several guidebooks for outdoor recreation in Munich.

\subsection{The Economic Value of Recreation}

The economic valuation of ES is often met with criticism. The natural environment has, for example, relevance and usefulness beyond immediate and potential utility [67]. Recreation in green spaces and woodlands can provide additional benefits for health such as physical exercise, aesthetic experiences, and intellectual stimulation [68]. However, recreation as an important ES for urban green spaces is often not included in valuation studies. For instance, four ES were valued in a study of the Schlosspark Nymphenburg in Munich [69]. Carbon sequestration, air pollution reduction, runoff reduction, and ground water recharge were assessed, while recreation was not considered at all, although it is one of the most frequented greenspaces in Munich and a prime destination for tourism.

For the two forests, we assumed more than 60,000 visitors in the center of the two forests. With punctual long-term monitoring at eight spots and two interview series, there is still some inaccuracy in the presented data. However, calculations could be based on actual recreational use of the forests. Most of the studies presented are based on household interviews to estimate the recreation value of forests-e.g., the Swiss socio-cultural monitoring [44]. For example, WTP analyses conducted by Elsasser \& Weller [45] only ask a question about "at least one visit to the forest". These studies assume that around $80 \%$ of the interviewees visited a forest at least once a year and used this as a baseline for calculation. Bernath et al. [64] estimate a recreation value of 30 Mio. Swiss Francs for the forests in Zurich. Dividing this figure by the forest size of [70] 2228.6 ha, this would be a recreation value of around 13,450 CHF per ha per year, which is roughly similar to our estimated travel cost approach for the urban proximate "Forest Adventure Trail". In The Netherlands, the recreation value for the 5200 ha of the De Wieden wetlands was estimated at 1,680,000 Euro [42].

\subsection{Importance of ES for Forest Visitors}

In our study, we could demonstrate a high appreciation for such assets as drinking water, biodiversity, and habitat for pollinating insects. These results are comparable with other recent studies in Germany [51,71,72]. Other studies indicate a high awareness of these features and the need for their conservation [47,73-75]. The BfN study [73] especially indicates broad support and willingness to pay for a better supply of various ES. 


\section{Conclusions}

In our study, we could demonstrate the difference between expert estimations, modelling, or household interviews to assess recreation compared to data collected on-site in the forest. We concluded that technical visitor counting can provide valuable information for many purposes. Although these methods still have some inaccuracies due to technical or installation problems, they provide more precise data on forest visitors in an actual forest. This also helps to determine more realistic recreation values of an actual forest based on actual uses. In our study, it also could be shown that woodlands are an attractive feature in urbanized areas, and people are prepared to travel long distances to find recreation in such a setting. This, in turn, demonstrates the large importance of socio-cultural ecosystem services. When expressed as monetary values, recreational services outscore others such as timber production. In this light, the costs or investments for recreation described by Seintsch et al. [31] provide values for society as a whole. The results from our study thus highlight the huge value of urban woodlands and their multifunctional management, and moreover, their value far beyond revenues gained from timber production. However, our results are not intended to play different ecosystem services against each other. As a consequence for forest management, this does not mean a one-sided focus, and moreover, maximizing single ecosystem services and neglecting others in urban forests, e.g., ceasing timber production. Looking at valuing the provisioning of non-market ecosystem services better and the ways in which forest owners can be better rewarded for the provision of many complimentary goods and services as a by-product of their integrated forest management should be discussed.

Acknowledgments: The authors would like to thank Stefan Huber, Thomas Stör, Herbert Rudolf, Alfred Fuchs (Freising Unit of the Bavarian State Forest Enterprise), Christel Steinhardt, Mayor Tobias Eschenbacher (City of Freising), and Roland Schreiber for supporting this work. The work presented in this paper is part of the "Urban Woodlands 2050" project. It is funded by the Bavarian State Ministry of Food, Agriculture, and Forestry. We would also like to thank Elizabeth Hamzi-Schmidt at the TUM English Writing Center for polishing the language.

Author Contributions: Gerd Lupp, Bernhard Förster, Valerie Kantelberg, Tim Markmann, Johannes Naumann, Carolina Honert, Marc Koch, and Stephan Pauleit conceived and developed the fieldwork design applying the camera traps for visitor counting and the interview designs. Bernhard Förster, Valerie Kantelberg, Carolina Honert, and Gerd Lupp worked on adapting the tools for assessing the data. Bernhard Förster, Valerie Kantelberg, Carolina Honert, Tim Markmann, Johannes Naumann, and Gerd Lupp analyzed the data. Gerd Lupp wrote the paper with the active support of all co-authors.

Conflicts of Interest: The authors declare no conflict of interest. The founding sponsors had no role in the design of the study; in the collection, analyses, or interpretation of data; in the writing of the manuscript, and in the decision to publish the results.

\section{References}

1. Norgaard, R.B. Ecosystem services: From eyeopening metaphor to complexity blinder. Ecol. Econ. 2010, 69, 1219-1227. [CrossRef]

2. Millenium Ecosystem Assessment. Ecosystems and Human Well-Being: Current, State and Trends; Findings of the Condition and Trends Working Group; Island Press: Washington, DC, USA, 2005; 948p.

3. Costanza, R.; d'Arge, R.; de Groot, R.; Farber, S.; Grasso, M.; Hannon, B.; Limburg, K.; Naeem, S.; O’Neill, R.V.; Paruelo, J.; et al. The value of the world's ecosystem services and natural capital. Nature 1997, 387, $253-260$. [CrossRef]

4. The Economics of Ecosystems and Biodiversity (TEEB). Mainstreaming the Economics of Nature a Synthesis of the Approach. Conclusions and Recommendations of TEEB; Progress Press: Valletta, Malta, 2010; 36p.

5. Naturkapital Deutschland-TEEB DE. Der Wert der Natur für Wirtschaft und Gesellschaft_Eine Einführung; Institut für Umweltplanung und Raumentwicklung (ifuplan): München, Germany; Helmholtz-Zentrum für Umweltforschung: Leipzig, Germany; Bundesamt für Naturschutz: Bonn, Germany, 2012; 90p. (In German)

6. Nowak, D.J. The effects of urban forests on the physical environment. In COST Action E12 Urban Forests and Urban Trees; Randrup, T.B., Konijnendijk, C.C., Christophersen, T., Nilsson, K., Eds.; Office for Official Publications of the European Communities: Luxembourg, 2002; pp. 22-42. 
7. Tyrväinen, L.; Pauleit, S.; Seeland, K.; de Vries, S. Benefits and uses of urban forests and trees: A European perspective. In Urban Forests and Trees in Europe; A Reference Book; Konijnendijk, C.C., Nilsson, K., Randrup, T.B., Schipperijn, J., Eds.; Springer: Berlin/Heidelberg, Germany, 2005; pp. 81-114.

8. Burkhardt, I.; Dietrich, R.; Hoffmann, H.; Leschnar, J.; Lohmann, K.; Schoder, F.; Schultz, A. Naturschutz und Biologische Vielfalt 63: Urbane Wälder; Bundesamt für Naturschutz: Bonn-Bad Godesberg, Germany, 2009; 214p. (In German)

9. Fryd, O.; Pauleit, S.; Bühler, O. The role of urban green space and trees in relation to climate change. CAB Rev. Perspect. Agric. Vet. Sci. Nutr. Nat. Resour. 2011, 6, 1-18. [CrossRef]

10. European Commission (EC). Green Infrastructure (GI)_Enhancing Europe's Natural Capital; Communication from the Commission to the European Parliament; The Council, The European Economic and Social Committee and The Committee of the Regions: Brussels, Belgium, 2013; p. 249. (In German)

11. Hunziker, M.; Freuler, B.; von Lindern, E. Erholung im Wald. Erwartungen und Zufriedenheit, Verhalten und Konflikte; Forum für Wissen; Der Multifunktionale Wald-Konflikte und Lösungen; Eidgenössische Forschungsanstalt WSL: Birmensdorf, Switzerland, 2011; pp. 43-51. (In German)

12. Bell, S.; Tyrväinen, L.; Sievänen, T.; Pröbstl, U.; Simpson, M. Outdoor recreation and nature tourism: A European perspective. Living Rev. Landsc. Res. 2007, 1. [CrossRef]

13. Forest Research. Benefits of Green Infrastructure; Report by Forest Research; Forest Research: Farnham, UK, 2010.

14. Cole, D.N. Management dilemmas that will shape wilderness in the 21st century. J. For. 2001, 99, 4-8.

15. Martens, D.; Bauer, N. Im test: Wald als ressource für psychisches wohlbefinden. Schweiz. Z. Forstwes. 2010, 3, 90-96. (In German) [CrossRef]

16. Eagles, P.F.; McCool, S.F. Tourism in National Parks and Protected Areas-Planning and Management; CABI Publishing: Oxon, NY, USA, 2002; 320p.

17. Ingold, P. Freizeitaktivitäten im Lebensraum der Alpentiere. Konfliktbereiche zwischen Mensch und Tier; Haupt: Bern/Basel, Switzerland, 2005; 516p. (In German)

18. Lupp, G.; Kantelberg, V.; Koch, M.; Schreiber, R.; Pauleit, S. Erholung in stadtnahen Wäldern-Beispiele München und Freising. AFZ Wald 2016, 4, 29-33. (In German)

19. Hoisl, R.; Nohl, W.; Engelhardt, P. Naturbezogene Erholung und Landschaftsbild; KTBL-Schrift 389; Landwirtschaftsverlag: Darmstadt, Germany, 2003; 306p. (In German)

20. Tyrväinen, L.; Silvennoinen, H.; Kolehmainen, O. Ecological and aesthetic values in urban forest management. Urban For. Urban Green. 2003, 1, 135-149. [CrossRef]

21. Stölb, W. Waldästhetik-Über Forstwirtschaft, Naturschutz und die Menschenseele; Kessel: Oberwinter, Germany, 2005; 400p. (In German)

22. Gasser, K.; Kauffmann-Hayoz, R. Wald und Volksgesundheit-Literatur und Projekte aus der Schweiz; Umwelt-Materialien Nr. 195; Bundesamt für Umwelt, Wald und Landschaft: Bern, Switzerland, 2005; 34p. (In German)

23. Gobster, P.H.; Nassauer, J.I.; Daniel, T.C.; Fry, G. The shared landscape: What does aesthetics have to do with ecology? Landsc. Ecol. 2007, 22, 959-973. [CrossRef]

24. Heyman, E. Analyzing recreational values and management effects in an urban forest with the visitor-employed photography method. Urban For. Urban Green. 2012, 11, 267-277. [CrossRef]

25. Rupf, R.; Wernli, M. Besuchermonitoring-Ein überblick über methoden und anwendungsbereiche. In VISIMAN. Beiträge zu Besuchermonitoring und Besuchermanagement in Pärken und Naturnahen Erholungsgebieten; Clivaz, C., Rupf, R., Siegrist, D., Eds.; Schriftenreihe des Instituts für Landschaft und Freiraum; HSR Hochschule für Technik Rapperswil: Rapperswil, Switzerland, 2013; pp. 27-36. (In German)

26. Clivaz, C.; Rupf, R.; Siegrist, D. (Eds.) VISIMAN. Beiträge zu Besuchermonitoring und Besuchermanagement in Pärken und Naturnahen Erholungsgebieten; Schriftenreihe des Instituts für Landschaft und Freiraum; HSR Hochschule für Technik Rapperswil: Rapperswil, Switzerland, 2013; 141p. (In German)

27. Siegrist, D.; Clivaz, C.; Hunziker, M.; Iten, S. (Eds.) Exploring the nature of management. In Proceedings of the Third International Conference on Monitoring and Management of Visitor Flows in Recreational and Protected Areas, Rapperswil, Switzerland, 13-17 September 2006; HSR Hochschule für Technik Rapperswil: Rapperswil, Switzerland, 2006; 509p. 
28. Raschi, A.; Trampetti, S. (Eds.) Management for protection and sustainable development. In Proceedings of the Fourth International Conference on Monitoring and Management of Visitor Flows in Recreational and Protected Areas, Montecatini Terme, Italy, 14-19 October 2008; 527p.

29. Goossen, M.; Elands, B.; Marwijk, R. Recreation, tourism and nature in a changing world. In Proceedings of the Fifth International Conference on Monitoring and Management of Visitor flows in recreational and Protected Areas, Wageningen, The Netherlands, 30 May-3 June 2010; Wageningen University and Research Centre: Wageningen, The Netherlands, 2010; 332p.

30. Fredman, P.; Stenseke, M.; Liljendahl, H.; Mossing, A.; Laven, D. (Eds.) The 6th International Conference on Monitoring and Management of Visitors in Recreational and Protected Areas. Outdoor Recreation in Change-Current Knowledge and Future Challenges, Stockholm, Sweden, 21-25 August 2012; Mid-Sweden University: Stockholm, Sweden, 2012; 415p.

31. Reimann, M.; Sepp, K.; Pärna, E.; Tuula, R. (Eds.) The 7th International Conference on Monitoring and Management of Visitors in Recreational and Protected Areas (MMV)_Local Community and Outdoor Recreation, Tallinn, Estonia, 20-23 August 2014; Tallinn University: Tallinn, Estonia, 2014; 317p.

32. Muhar, A.; Arnberger, A.; Brandenburg, C. Methods for visitor monitoring in recreational and protected areas: An overview. In Proceedings of the Monitoring and Management of Visitor Flows in Recreational and Protected Areas, Vienna, Austria, 30 January-2 February 2002; pp. 1-6.

33. Bayerische Staatsregierung. Richtlinien für die Forsteinrichtung im Körperschaftswald (FER-KöW 2012); Bekanntmachung des Bayerischen Staatsministeriums für Ernährung Landwirtschaft und Forsten; Az.: F3-7774-1/210; Bayerische Staatsregierung: München, Germany, 2012. (In German)

34. Küppers, J.-G.; Dieter, M. Belastungen der Forstbetriebe aus der Schutz- und Erholungsfunktion des Waldes; Arbeitsbericht 2008/4 des Institutes für Ökonomie der Forst- und Holzwirtschaft; Johann Heinrich von Thünen-Institutes Bundesforschungsinstitut für Ländliche Räume, Wald und Fischerei: Hamburg, Germany, 2008; 29p. (In German)

35. Seintsch, B.; Ermisch, N.; Dög, M. Ist ein Mehraufwand durch Schutz- und Erholungsleistungen nachweisbar? AFZ Wald 2013, 68, 10-12. (In German)

36. Wolff, M.; Sieberth, L.; Asche, N. Ökosystemdienstleistungen von Wäldern. AFZ Wald 2016, 2, $25-27$. (In German)

37. Riera, P.; Signorello, G.; Thiene, M.; Mahieu, P.-A.; Navrud, S.; Kaval, P.; Rulleau, B.; Mavsar, R.; Madureira, L.; Meyerhoff, J.; et al. Non-market valuation of forest goods and services: Good practice guidelines. J. For. Econ. 2012, 18, 259-270. [CrossRef]

38. Schweppe-Kraft, B.; Grunewald, K. Approaches to the economic valuation of natural assets. In Ecosystem Services-Concept, Methods and Case Studies; Grunewald, K., Bastian, O., Eds.; Springer: Berlin/Heidelberg, Germany, 2015; pp. 85-104.

39. Rumble, H.; Rogers, K.; Doick, K.; Hutchings, T. Valuing Wrexham's Urban Forest. Assessing the Ecosystem Services of Wrexham's Urban Trees: A Technical Report. 2014. Available online: http://www.forestry.gov.uk/pdf/FR_Doick_Wrexham_iTree_Full_Report_2015.pdf/ $\backslash$ protect $\backslash T 1 \backslash$ textdollarfile/FR_Doick_Wrexham_iTree_Full_Report_2015.pdf (accessed 20 September 2016).

40. Gantioler, S.; Rayment, M.; Bassi, S.; Kettunen, M.; McConville, A.; Landgrebe, R.; Gerdes, H.; Ten Brink, P. Costs and Socio-Economic Benefits Associated with the Natura 2000 Network; Final Report; European Commission, Directorate-General Environment; Institute for European Environmental Policy/GHK/Ecologic: Brussels, Belgium, 2010; 122p. (In German)

41. Woltering, M. Ökonomische effekte von Großschutzgebieten. Naturschutz Landschaftsplan. 2012, 44, 325-331. (In German)

42. Hein, L.; van Koppen, K.; de Groot, R.S.; van Ierland, E.C. Spatial Scales, stakeholders and the valuation of Ecosystem services. Ecol. Econ. 2006, 57, 209-228. [CrossRef]

43. Elsasser, P.; Meyerhoff, J.; Montagné, C.; Stenger, A. A bibliography and database on forest valuation studies from Austria, France, Germany and Switzerland-A possible base for a concerted European approach. J. For. Econ. 2009, 15, 93-107. [CrossRef]

44. Von Grünigen, S.; Montanari, D.; Ott, W. Wert der Erholung im Schweizer Wald. Schätzung auf Basis des Waldmonitorings Soziokulturell (WaMos 2); Umwelt-Wissen Nr. 1416; Bundesamt für Umwelt: Bern, Switzerland, 2014; 46p. (In German) 
45. Elsasser, P.; Weller, P. Aktuelle und potenzielle erholungsleistung der wälder in Deutschland. Monetärer nutzen der erholung aus sicht der bevölkerung. Allg. Forst Jagdztg. 2013, 184, 84-96. (In German)

46. Roovers, P.; Hermy, M.; Gulinck, H. Visitor profile, perceptions and expectations in forests from a gradient of increasing urbanisation in Central Belgium. Landsc. Urban Plan. 2002, 59, 129-145. [CrossRef]

47. Lupp, G.; Konold, W. Landscape preferences and perception of both residents and tourists: A case study in the Müritz National Park (Germany). In Visitor Management in Nature-Based Tourism-Strategies and Success Factors for Parks and Recreational Areas; Siegrist, D., Clivaz, C., Hunziker, M., Iten, S., Eds.; Series of the Institute for Landscape and Open Space; University of Applied Sciences Rapperswil: Rapperswil, Switzerland, 2008; pp. 47-58.

48. Markmann, T. Erholungsnutzung und Waldwahrnehmung der Freisinger Wälder. Master's Thesis, Technical University of Munich, Freising, Germany, 2015; 90p. (In German)

49. Bernard, H.R.; Pelto, P.J.; Werner, O.; Boster, J.; Romney, A.K.; Johnson, A.; Ember, C.R.; Kasakoff, A. The construction of primary data in cultural anthropology. Curr. Anthropol. 1986, 27, 382-395. [CrossRef]

50. Arnberger, A.; Hinterberger, B. Visitor monitoring methods for managing public use pressures in the Danube Floodplains National Park, Austria. J. Nat. Conserv. 2003, 11, 260-267. [CrossRef]

51. Lupp, G.; Syrbe, R.U.; Steinhäußer, R.; Bastian, O. Perception of energy crops by laypersons and farmers using the approach of ecosystem services. Morav. Geogr. Rep. 2014, 22, 15-25.

52. Cessford, G.; Muhar, A. Monitoring options for visitor numbers in national parks and natural areas. J. Nat. Conserv. 2003, 11, 240-250. [CrossRef]

53. Xia, J.; Arrowsmith, C.A. Techniques for counting and tracking the spatial and temporal movement of visitors. In Monitoring, Simualtion, and Management of Visitor Landscapes; Gimblett, H.R., Skov-Petersen, H., Eds.; The University of Arizona Press: Tucson, AZ, USA, 2008; pp. 85-106.

54. Von Janowsky, D.; Becker, G. Characteristics and needs of different user groups in the urban forest of Stuttgart. J. Nat. Conserv. 2003, 11, 251-259. [CrossRef]

55. Zandersen, M.; Richard, S.J.; Tol, R.S.J. A meta-analysis of forest recreation values in Europe. J. For. Econ. 2009, 15, 109-130. [CrossRef]

56. Sieberth, L. Inwertsetzung von Ökosystemdienstleistungen-Eine objektive Bewertung auf lokaler Ebene —Remscheid-Eine Studie im Auftrag der Waldgenossenschaft Remscheid eG. 2014. Available online: http://www.waldgenossenschaft-remscheid.de/wp-content/uploads/2016/05/kosystemleistungen-Wlder-im-Stadtgebiet-Remscheid.pdf (accessed on 23 July 2016). (In German)

57. Bastian, O.; Stein, C.; Lupp, G.; Behrens, J.; Renner, C.; Grunewald, K. The appreciation of nature and landscape by tourism service providers and visitors in the Ore Mountains (Germany). Landsc. Online 2015, 41, 1-23. [CrossRef]

58. Arnberger, A.; Haider, W. Social effects on crowding preferences of urban forest visitors. Urban For. Urban Green. 2005, 3, 125-136. [CrossRef]

59. Naumann, J. Untersuchung der Wegenutzung am Grünten Durch Unterschiedliche Nutzergruppen. Master's Thesis, Technical University of Munich, Freising, Germany, 2016; 137p. (In German)

60. Arnberger, A. Recreation use of urban forests: An inter-area comparison. Urban For. Urban Green. 2006, 4, 135-144. [CrossRef]

61. Wippermann, C.; Wippermann, K. Mensch und Wald: Einstellungen der Deutschen zum Wald und zur nachhaltigen Waldwirtschaft; Bertelsmann: Bielefeld, Germany, 2010; 182p. (In German)

62. Tyrväinen, L.; Uusitalo, M.; Silvennoinen, H.; Hasu, E. Towards sustainable growth in nature-based tourism destinations: Clients' views of land use options in Finnish Lapland. Landsc. Urban Plan. 2014, 122, 5-13. [CrossRef]

63. Jensen, F.; Koch, N. Twenty five years of forest recreation research in Denmark and its influence on forest policy. Scand. J. For. Res. 2004, 19, 93-102. [CrossRef]

64. Bernath, K.; Roschewitz, A.; Studhalter, S. Die Wälder der Stadt Zürich als Erholungsraum. Besuchsverhalten der Stadtbevölkerung und Bewertung der Walderholung; Eidgenössische Forschungsanstalt für Wald, Schnee und Landschaft: Birmensdorf, Swtizerland, 2006; 43p. (In German)

65. Bernath, K.; Roschewitz, A. Recreational benefits of urban forests: Explaining visitors' willingness to pay in the context of the theory of planned behavior. J. Environ. Manag. 2008, 89, 155-166. [CrossRef] [PubMed]

66. Tyrväinen, L. Use and valuation of urban forest amenities in Finland. J. Environ. Manag. 2001, 62, 75-92. [CrossRef] [PubMed] 
67. Kumar, M.; Kumar, P. Valuation of the ecosystem services: A psycho-cultural perspective. Ecol. Econ. 2008, 64, 808-819. [CrossRef]

68. Daniel, T.C.; Muhar, A.; Arnberger, A.; Aznar, O.; Boyd, J.W.; Chan, K.M.A.; Costanza, R.; Elmqvist, T.; Flint, C.G.; Gobster, P.H.; et al. Contributions of cultural services to the ecosystem services agenda. Proc. Natl. Acad. Sci. USA 2012, 109, 8812-8819. [CrossRef] [PubMed]

69. Aevermann, T.; Schmude, J. Quantification and monetary valuation of urban ecosystem services in Munich, Germany. Z. Wirtschaftsgeogr. 2015, 59, 188-200. [CrossRef]

70. Stadt Zürich Der Züricher Wald in Zahlen. Available online: https://www.stadt-zuerich.ch/ted/de/index/ gsz/natur-_und_erlebnisraeume/stadtwald/der_zuercher_wald_in_zahlen.html (accessed on 13 June 2016).

71. Federal Agency for Nature Conservation (BfN). Naturbewusstsein 2011-Bevölkerungsumfrage zu Natur und Biologischer Vielfalt; Federal Agency for Nature Conservation: Bonn, Germany, 2011; 81p. (In German)

72. Grunewald, K.; Syrbe, R.-U.; Renner, C. Analyse der ästhetischen und monetären Wertschätzung der Landschaft am Erzgebirgskamm durch Touristen. GEOÖKO 2012, 33, 34-65. (In German)

73. Federal Agency for Nature Conservation (BfN). Naturbewusstsein 2009_Bevölkerungsumfrage zu Natur und Biologischer Vielfalt; Federal Agency for Nature Conservation: Bonn, Germany, 2009; 66p. (In German)

74. Kleinhückelkotten, S.; Wippermann, C.; Behrendt, D.; Fiedrich, G.; de Magalhaes, I.S.; Klär, K.; Wippermann, K. Kommunikation zur Agro-Biodiversität. Voraussetzungen für und Anforderungen an eine Integrierte Kommunikationsstrategie zu Biologischer Vielfalt und Genetischen Ressourcen in der Land-, Forst-, Fischerei- und Ernährungswirtschaft (Einschließlich Gartenbau); ECOLOG-Institut/Sinus Sociovision: Hannover/Heidelberg, Germany, 2006; 189p. (In German)

75. Umweltbundesamt (UBA). Umweltbewusstsein und Umweltverhalten der Sozialen Milieus in Deutschland; German Environment Protection Agency: Dessau-Roßlau, Germany, 2009; 132p. (In German)

(C) 2016 by the authors; licensee MDPI, Basel, Switzerland. This article is an open access article distributed under the terms and conditions of the Creative Commons Attribution (CC-BY) license (http://creativecommons.org/licenses/by/4.0/). 